\title{
The Concept of Law and Justice in Hamlet
}

Bishwa Nath Lamichhane

https://doi.org/10.3126/litstud v29i01.39595

\begin{abstract}
This work strives to explore the concept of law, and justice in Hamlet, one of the greatest works of Shakespeare in the seventeenth century. According to Richard Posner "Law and literature are very old fields..." (5). So, this paper attempts to examine the question of Hamlet's legal, political, legitimacy in his thought and action. It also tries to observe whether Claudius is a legitimate or illegitimate figurehead of the then existing state of Denmark. Hamlet, the greatest work of Shakespeare in the early modern age, portrays the protagonist sandwiched between the divine laws and Christian moral values and the practicality of human laws and the expediencies of present realities. The problem with Hamlet is what he calls in his soliloquy, 'to be or not to be' - ambivalence and procrastination in taking action. Hamlet represents a great legal dilemma. Hamlet tries to be perfect by observing both the natural law and justice and the existing human laws of the state. Hamlet is torn between the divine will, human reason and Christian moralities prohibiting taking revenge. The paper concludes with Hamlet's tragic end as a consequence of his vacillation between the divine will and the human law. Hamlet mirrors jurisprudential dilemma.
\end{abstract}

As one of the greatest works of Shakespeare, critics have never been tired of writing on Hamlet and critiqued it from different perspectives. As Michael Freeman contends, "there are many entanglements of law and literature in Shakespeare. There is a substantial critical literature on Shakespeare and the law" (1467). As such this paper tends to consider Hamlet from legal perspective. Posner writes, "Law and literature are very old fields, but could not emerge as a field until legal scholarship and literary scholarship were no longer autonomous fields ..." (5).

It is thus quite sensible to observe the question of legal and political theory concerning representations of law, sovereignty and justice in this all time talked work. It is important to explore how the play emphasizes the natural law and justice and the failure to maintain it by its protagonist. From the perspective of natural law, is Claudius legitimate figurehead of the state? The practical reason of the exercise of law is seriously flawed. Although Claudius tries to cover up himself (his guilt) by announcing Hamlet his successor, the people of Denmark remain in illusion until Hamlet does not prove his hidden guilt in the end. But he could do it at the cost of his own life and lost his position as the sovereign of the State of Denmark. Paul Raffield and Gary Watt rightly argue in their work Shakespeare and the Law that there is:

...an invitation to learn the lesson of Hamlet and to apply it to the problem, present in our own time, of sovereign seizure of the treasures of the earth. The lesson is that the person of the monarch and the treasure of the realm are one and the same by prerogative right; the thing to be learned is that just because it is a prerogative does not mean that it signifies a right. (3)

On the other hand if Claudius is a usurper and violator of the natural law, Hamlet's own actions are also open to legal and moral critique. It is not clear whether Hamlet's concern is: to take a private revenge or maintain public justice in 
the state. If it was private revenge why didn't he kill him when he got several chances and if it was for natural justice why couldn't he leave him to the final judgment of God in heaven? Shakespeare depicts the ambivalence of the audience of the early modern period by putting Hamlet in two situations: "The time is out of joint. O cursed spite/That ever I was born to set it right!" (I.5.197-198), and "There's a divinity that shapes our ends/Rough-hew them how we will... The readiness is all" (V.2.10-11). Hamlet wants to revenge as did the Greeks heroes but is shackled by the biblical warnings, "Avenge not yourselves, but rather give place unto wrath: for it is written, Vengeance is mine; I will repay, saith the Lord ..." (Romans 12:19).

About Claudius there is no doubt that he is a usurper and breaker of natural law as well as moral and ethical values as he killed his brother- king Old Hamlet and married his sister-in-law which was regarded incestuous during that period. But one could ask then- in what sense is Hamlet correct in killing Claudius, the sovereign of the state for his private revenge? Why could not he bring him before the public justice and punish him according to the then existing laws to punish the usurper and the one who committed regicide? There are other questions like Hamlet's feigned madness or his relation to Ophelia and so on which the paper does not bother to address. This short paper rests with its search for legal/moral/ethical ground for the actions of its two major characters - Hamlet and his usurper uncle Claudius.

Is Claudius a Corrupt and Illegitimate/Legitimate Sovereign?

In Act IV Scene 2, when Rosencrantz asks Hamlet where the body is and he must go with him to the king, he replies: "The Body is with the King, but the King / is not with the Body. The king is a thing -Of nothing" (IV.2.28-30). Here, as always, Hamlet speaks with ambiguity, in a roundabout way, allusive, satiric, and sarcastic way. This is a "riddling reference to the theory of king's two bodies, natural and politic, made famous in Kantorowicz's book, King's Two Bodies" (Edwards, 187). According to this theory, a king has two capacities - one is his own natural/physical body consisting of natural members and the other is his political body, i.e. his body with his subjects. Hamlet in these lines alludes to the doctrine of "the King's two bodies', the idea that a monarch has both a normal, mortal body and a mystical, spiritual body as the epitome of his realm. As usual Hamlet's meanings are equivocal and multiple to the Kingship, but that the true King -either the Old Hamlet or he himself - is not identical with the body (referring to Claudius) who is now pretending to be the King. That is why he says 'the King is a thing of nothing'. The king's (Old Hamlet) natural body is dead and the new king who has the body politic is not a real/legitimate king and that is why he is a king of nothing. Hamlet was written at a time when theories of natural law and common reason were being challenged by the work of contemporary theorists. The theories of 'reason of state' were becoming increasingly popular. Machiavelli paved the way for a political doctrine that espoused the securing of the sovereign's power and protecting the stability of the state. According to Machiavellian concept of 'reason of state' it does not make Claudius to be an illegitimate figurehead of law because for Machiavelli whatever evils he commits to obtain the crown is justified.

A consideration of modern positivist approach to law may support to Claudius's legitimacy of ruling. As a king, Claudius is the body of law and hence he must be obeyed by his subjects. According to John Austin's command theory, "a law is a command which obliges a person or persons to a course of conduct and proceeds by way of a relationship of superiority" (Morrison, 216). According to Austin, law is a command issued by the uncommanded commander - the sovereign. In this regard Claudius is a legitimate ruler, even if a secret crime haunts his history. 
Any commands are laws: the laws he creates are valid and that must be obeyed by the people. So sure is Claudius that his position is directly below God that when Laertes threatens him by asking his father, he warns him by saying, /There's such a divinity doth hedge a king /That treason can but peep to what it would, /Acts little of his will. (IV. 5.26-28).

Thomas Aquinas' providential theory of kingship coupled with the notion of the divine right of kings legitimates Claudius' regal authority. But despite this assertion of his divine right of rule there appear to be some questions in the play that Claudius is not the lawful successor to Old Hamlet as there was elective monarchy in Denmark. Can a person who killed his brother (king), and whored his own sisterin-law be a legitimate king of Denmark? Can regicide be neglected simply on the basis of Machiavellian terms? Did he come by election? As Hamlet rightly says to Horatio:

Does it not, think thee, stand me now upon?

He that hath killed my king, and whored my Mother

Popp'd in between th'Election and my Hopes

Thrown out his Angles from my proper Life,

And with such Cus'nage, is it not perfect Conscience

To quit him with his Arms? And i'st not to be damned

To let this Canker of our Nature come in further Evil? (V.2.63-72)

This shows that Hamlet was the rightful heir to the throne and Claudius was a usurper. Although Hamlet's statement to Horatio may simply be evidence of his hope that he will succeed his father, it does seem that Hamlet actually believes that Claudius has usurped his position as rightful king. In Act I when Claudius addresses Hamlet as 'my Cousin Hamlet and my son', Hamlet curtly replies: "A little more than a Kin and less than Kind" (I.2.65). These words show a deep-rooted resentment at what he sees to be the injustice of Claudius' appropriation of the crown.

But applying HLA Hart's approach to legal positivism, it is quite natural for the Danes to obey Claudius' laws. As Morrison argues quoting Hart: "To command is characteristically to exercise authority over men, not power to inflict harm, and though it may be combined with threats of harm a command is primarily an appeal not to fear but to respect for authority" (Morrison, 355). This means there is no way but to fear and respect the laws of the ruling authority. But it would be surprising if during Old Hamlet's reign, murdering one's predecessor was seen in accordance with any accepted legal rule of legitimate succession. Regicide would not be accepted in state like Denmark which followed an elective monarchy. And even from the Hartian positivist analysis we can challenge Claudius' role as Denmark's king and divine lawmaker.

It seems that the most powerful and effective critique of Claudius' rule emerges when the monarch's power is defined in accordance with principles of natural law and natural justice. If law has an inherently moral basis, then the legitimacy of the reign of a monarch whose actions in gaining the crown were clearly and wholly immoral can surely be challenged. The idea of higher natural law existing over and above the law of sovereign powers of the earth can be traced back 
to Thomas Aquinas. As Friedmann states:

St Thomas defines law as an ordinance of reason for the common good made by him who has the care of the community and promulgated... since the world is ruled by divine providence, the whole community of the universe is governed by divine reason. Divine law is supreme.... (108)

The works of the moral and political theorists like Machiavelli, Bodin, Grotius, Hobbes, Locke, among others during the fifteenth and sixteenth centuries, when considered in connection with the example of a monarch like Claudius exercising virtually unrestrained power, challenge the natural law principles. For example, for Cicero natural law is over and above all human effort and the positive law is measured on the scale of natural law. As Friedmann argues, "For Cicero it emphatically has that function: It is not allowable to alter this law, nor deviate from it, nor can it be abrogated. Nor can we be released from this law, either by the Senate or by the people" (102).

Even though people may have constituted a state by social contract by choosing a form of government suitable for them, they are in a trap of such rulers representing the government. Friedmann, quoting Grotius says: "once the people have transferred their right of government to the ruler - whether in order to find a protector against danger or because they preferred autocratic rule to liberty, or as a result of war - they forfeit the right to control or punish the ruler however bad his government" (119). Similarly German jurist Christian Wolff was in favour of absolutism of the sovereign... (Koul 147). In Leviathan, Thomas Hobbes described the condition of man as "solitary, poor, nasty, brutish and short" (Ratnapala, 147) and he maintained that "individual autonomy is surrendered to the sovereign in exchange for the sovereign's protection (Ratnapala, 147-149). Hobbes was convinced that the sovereign, in order to perform its functions adequately, should be omnipotent and not subject to legal restrains (Bodenheimer, 41). Austin placed the sovereign at the highest position - "The sovereign is not himself bound by any legal limitations, whether imposed by superior principles or by his own laws. Any higher principles or self-limitations are merely guides which the sovereign may discard" (Friedmann, 260). The writers and scholars in the academia have also been great advocates of power and they have strongly emphasized the rule of power and assigned greater share of power in the hands of the rulers which has given birth to dictators and usurpers, regicide and blood bath for occupying the seat of power. As Julius Stone argues, "on the one hand, that coercive power is a practical necessity for organized society, so that power must have its legitimacy; and on the other hand, that such power must ever be questioned, and challenged to legitimize itself before reason" (37).

Notwithstanding the above arguments for Claudius' legitimacy, there are other ample reasons which may be used to question his position as the king of Denmark. That is when a monarch's power is defined in accordance with principles of natural law and justice there is ample space to critique Claudius' position. In this regard if law has moral basis on which it stands, then a monarch who has usurped the power immorally can surely be challenged. Has Claudius reached his position by legal and democratic way which, the then Denmark used to observe? Thus from the modern positivistic or from classical naturalists' and/or contractualists' approach Claudius may be a legitimate ruler but from the moral and ethical point of view he loses the ground. Some critics think that Hamlet is an epitome of death or he is centered on death, a severe threat to the ruling sovereign and try to legitimize every 
step taken by Claudius in order to maintain law and order in the state of Denmark. But it is quite obvious to think that Claudius perceived Hamlet as a threat to everyone - his existence and his rule in Denmark. After he kills Polonius he senses his own death and rightly realizes: "His Liberty is full of Threats to all, / to you, yourself, to us, to everyone" (IV.1.14-15). Claudius realizes that Hamlet is not only personally a threat to him but he is also exciting the 'distracted multitude' against him who cannot judge except on the basis of what is seen by their eyes. And the offender is going wayward. A little later he further realizes:

How dangerous is it that this Man goes loose, /Yet must not we put the strong Law on him: /He's lov'd of the distracted Multitude, /Who like not in their Judgement but their Eyes, /And where 'tis so, th' Offender's Scourge is wayed, /Buy never the Offence. To bear all smooth and even, /Sudden sending him away must seem deliberate Pause; diseases desperate grown /By desperate Appliance are reliev'd /Or not at all". (IV.3.2-10)

Therefore whatever Claudius is doing is for protecting the state and acting for the common good as the sovereign of the state. One could argue that deaths upon deaths are accrued due to Hamlet - from the killing of Rosencraus and Guildenstern to killing Polonius, to driving Ophelia commit suicide and finally four deaths - his opponent Laertes, his own mother Gertrude, his uncle and king Claudius and his own in the last scene of fencing swords. Hamlet could be criticized on his abnormal behavior and his cruelty and never repenting on his misdeeds. What is his main purpose and who is his main enemy whom he wants to kill? It is certainly Claudius who killed his father and 'whored' his mother. But he kills every one that comes on his way. For example when he killed Polonius who was hiding in his mother's room, he repents but quickly legitimizes and rationalizes his deed as the Heaven's pleasure to choose him as its agent. As he says "...but Heaven hath pleas'd it so/To punish me with this, and this with me, /That I must be their Scourge an Minister." (III.4.170-173). Hamlet is never going to turn back from his journey of killing and is never going to realize his mistake but when made mistake, quickly shift the blame to the fate or heaven. Even after killing innocent Polonius he further says to his mother: "I must be cruel only to be kind: / This Bad begins, and Worse remains behind" (III.4.175-176). So Hamlet emerges like a serial killer in the play.

But critics have never tried to peep on the severe crime on the part of Gertrude in this tragedy of death and devastation. It is only Hamlet who realizes that his mother is not less guilty in bringing the death and decay in the state of Denmark. He rightly says: "Frailty, thy name is woman" in scene two of Act one. Hamlet is poisonously disturbed by her over hasten marriage with his uncle. In fact Claudius also realizes this trouble of Hamlet. So Gertrude's complicity in Claudius' crime should not be given less weight. In fact Gertrude is the root cause of the whole problem. Had she not started her affair with Claudius he may not have dared to kill her husband. It is women's cause that has caused the greatest havoc in the history of human civilization. For instance we can take the case of Trojan War to religious texts like Bible to Ramayana to Mahabharata. On the other hand the cruelty of Hamlet toward Ophelia cannot be exaggerated more. For example Ophelia's innocent love is retorted by: "Get thee to a Nunn'ry, why ould'st thout be a Breeder of Sinners?" (III.1.119). This sarcastic statement is repeated five times in less than fifty lines. Can there be more cruel reply than this? But still after such a mockery, ridicule and derision Ophelia has never less love, owe and wonder for Hamlet. Even after hearing this heart cutting, acidic reply, Ophelia wonders: "O what a Noble 
Mind is her o'evrthown!" (III.1.153). Can a prince who is in search of justice do such a heartless treatment to his lover? Why should he project his father's suffering in his own life, by saying “...go to, I'll no more /on't, I hath made me mad. I say we will have /no moe Marriage; those that are married / already, all but one shall live, the rest / shall keep as they are" (III.49-53). Thus Hamlet is a usurper of her emotions.

Is Hamlet a sovereign lawmaker? A Machiavellian Prince? A Christian Holy Figure? In his most controversial work The Prince, Niccolo Machiavelli draws very harsh picture of men suggesting the prince. He gives excessive importance to power and says that "men cannot make themselves secure without power" (Bondanella and Musa, 173). So he thinks that it is better to be powerful and feared than powerless and loved. As he suggests:

From this arises an argument: whether it is better to be loved or the contrary. I reply that one should like to be both one and the other; but since it is difficult to join them together, it is much safer to be feared than to be loved when one of the two must be lacking. For one can generally say this about men: that they are ungrateful, fickle, simulators and deceivers, avoiders of danger, greedy for gain.... (56)

Although not a de-facto representation of the law and order, Hamlet as a legitimate prince of the state of Denmark must convince the people of his princely qualities. So the natural question is, what kind of sovereign lawmaker would be the prince Hamlet, and how would he lead the state. Would he turn out to be Plato's philosopher king or Machiavellian prince? What does his present nature of over brooding, hesitant in action, falling prey to indecision, delay in avenging his father's death by his uncle suggest of him? How long would he take to make new laws necessary for Danish people? His excessive meticulousness and pernickety would entangle him on the process rather than reaching the substance. His action ends in his thought - "words, words, words" (II.2.98), and his majestic status turns into mere "congregation of vapours" (II.2.32).

"Elizabethan writers were scandalized and intrigued by what they saw as a typically Machiavellian character - although the character was most often a Senecan villain in doublet and hose" (Bondanella, XI). Shakespeare could not neglect this common picture of a hero or rather a Machiavellian character. But Shakespeare moulds hamlet's mind in the furnace of Christianity that "placed supreme happiness in humility and contempt for worldly objects" (Morrison, 76). That is why he makes Hamlet express "How wary, stale, flat and unprofitable / Seem to me all the uses of this world?" (I.2.133-34). Hamlet is also exasperated just like T.S. Eliot to see the wretched condition and expresses his contempt toward the moral, ethical degraded culture of Denmark, that is, the "king taking his rouse" and Hamlet answers Horatio's query that it was a custom, "...it is a custom / More honour'd in the /Breach than the observance" (I.4.14-15). Here Shakespeare is speaking through Hamlet what the Protestant-dominated England would loath the spree of the king and the courtiers. Hamlet is also very anxious that his cultural decay has made other nations tradust' (insult) and 'taxed' (vilified) and the Danes seem ass-like. He further complains:

This heavy headed Reveale East and West / Makes us tradust, and taxed of other Nations: /They clip us drunkard and with Swinish Phrase / Soil our Addition; and indeed it takes / From our Achievements, though perform'd at Hight, / The Pith and Marrow of our Attribute. (I.4.16-21) 
If it is this concern that eats Hamlet's mind what kind of law would he make? Undoubtedly he would opt for Protestant self-disciplinary codes of conduct and of course, what Nietzsche calls Apollonianism. But the question is: how can Hamlet sail safely putting one of his legs into the Christian (Protestant) boat and the other leg into the Machiavellian boat? I mean how can he be successful if he wants to be a pure Christian follower and be bold and fearful enough to his enemy? In his suggestion to the Prince, Machiavelli argues: "Cesare Borgia who was considered cruel but whose cruelty brought order to Romagna united it, restored it to peace and obedience, and ensures him not to be afraid of any reproach of cruelty" (55). Machiavelli thinks that people are ungrateful, fickle, simulators, deceivers and as such he advises the prince: "it is much safer to be feared than to be loved" (56). From this point of view, Claudius is the best model and Hamlet should try to be like him. What Claudius did is forgivable for he did it for what Giovanni Botero calls 'The Reason of State' and for the common good. So Hamlet is under the double anti-directional yokes and torn and limited to utter soliloquy as a pang of these opposing forces.

Another question that emerges from the situation is: what is the best recourse to take when one is in the pursuit of law and justice? Is it at individual level, or does it indicate toward the recourse to public solution to a new formation of law or seeking justice for any injustice? In this regard can Hamlet's pursuit of justice go outside the state laws and take the form of personal/private revenge? Because the Old Hamlet was not only his father but also the established monarch of the state of Denmark, why couldn't he go to the public with this case of regicide and arouse them against the usurper Claudius like Antony did in Julius Caesar? Was the state-law of Denmark so weak that Hamlet had to feign to have gone mad in order to find out the proof of Claudius' guilt? And even at the point of Hamlet's success in killing Claudius, wouldn't it be another regicide? So, modern audience may find Hamlet failed, in both wisdom and prudentia.

Law is something that Shakespeare cannot avoid speaking- either directly or indirectly as an oxymoron. Law is either mocked, condemned or questioned in paradoxes of its roles. In the Second Part of King Henry VI, when Jack Cade brags of his false lineage and his Kingly state, Shakespeare speaks from the mouth of his character, Dick, "The first thing we do, let's kill all the lawyers" (Act IV, Scene II. 71). Although this might have multiple meanings, the direct and surface implication is a hatred of the speaker toward the lawyers. If hatred for the bad lawyer could be one interpretation the line may be a compliment for the profession. But most importantly Shakespeare may have intended a kind of ambiguity and multiplicity of his expression.

In his famous soliloquy 'To be or not to be is the Question' in Act III scene 1, Shakespeare clearly indicates that the intervention of law would delay or hinder the achievement of justice and complains bitterly on the "Law's Delay" (III.1.71). Here also Hamlet hesitates to settle the account by using his 'bare Bodkin' (unsheathed dagger) and realizes that this could result in his damnation as it would be a regicide to kill a king somehow accepted by the people as the new king. So it is very difficult to account how Hamlet would react to such a situation. Now that Claudius is guilty (as claimed by the ghost) is proved by his reaction in the play The Mousetrap. What stops Hamlet to take action immediately and take revenge is not understandable. This certainly gives ample space to believe that he is suffering from Freudian concept of Oedipal complexity. He fails in his claim that "The Time is out of Joint... / that ever I was born to set it right" (I.5.178-79). His greatest problem is 
to think too much on "To be or not to be" and take action rashly when it is time to think clearly. He is the epitome of best thought and the worst action. It would be apt to say: 'Procrastination thy name is Hamlet'. If one plausible reason for Hamlet not taking action is: he is somewhere deep inside filled with the Christian morals which are clearly against any revenge; another reason could be his conscience and fears of the divine damnation of committing regicide. Thus Hamlet is a philosopher in his thought and a Machiavellian villain in his rash acts.

\section{Perfection Denied: The Tragic End of Hamlet}

None of the tragedies of Shakespeare has evoked so much and so long debate, controversy and confusion to critics and readers than Hamlet. There are as many interpretations as there are critics on it. The more is said about Hamlet the more seems to be left to explore. Hamlet has become as enigmatic and intriguing as Leonardo da Vinci's Mona Lisa. The eternal question in Hamlet's interpretation is what exactly was the reason behind Hamlet's delay in taking action? Whether Hamlet was successful or a failure is the question that spawned so many critiques and comments. There are obviously two camps in this - one line thinks that he was a successful hero and the other line thinks that he was, after all, a failed protagonist doomed to meet his tragic end. Some eighteenth century critics like John Dennis, quotes John F. Andrews, thought to be "wanting in the exact distribution of poetical justice" (331). Hamlet wants to revenge his father's murderer who is ruling the state of Denmark but the justification for this is not on the solid ground of factual proof. It is a call from Heaven as the dead king rises from the grave and urges him to avenge. This entry of the ghost from the beginning reduces the credit of Hamlet's effort in setting the account with his uncle, Claudius.

So there is the entry of the providence in directing Hamlet to clean and weed the variegated garden which is culturally rotten Denmark. This shows the direct intervention of divine power in the play. Now the question - whether Hamlet was successful to carry on this order or he was a failure is the most debatable question that has consumed so much ink and so many papers by the critics since the seventeenth century. If we take the Hamlet of his soliloquy he speaks like an omniscient philosopher who knows everything in the world. But if we take the Hamlet on the practical ground he is so fickle, changing his moods, undecided, rash and villainous in action. The greatest problem with Hamlet is he wants to obey the divine order on the one hand and does not want to redden his hand with regicide. On the other hand we may again sympathize Hamlet for his blunders and delay in action for the reason that "The greatest minds are capable of the greatest vices as well as the greatest virtues and those who perceive very slowly may, provided they always follow the straight road, really advance much faster than those who, though they run, forsake it" (Descartes 71-72).

\section{Works Cited}

Andrews, John F. (Ed). Hamlet, London: Everyman, 1998.

Bondanella, Peter and Musa, Mark. The Portable Machiavelli. New York: Penguin Books, 1979.

Descartes, Rene. Key Philosophical Thinking. Trans. Ross, G.R.T. Hertfordshire: Wordsworth Classics, 1997.

Freeman, Michael. Lloyd's Introduction to Jurisprudence. London: Sweet \& 
Maxwell, 2014.

Friedmann, W. Legal Theory. New Delhi: Universal Law Publishing Co. Pvt. Ltd., 2011.

Koul, Autar Krishen. Jurisprudence. New Delhi: Universal Law Publishing Co., 2010 .

Machiavelli, Niccolo. The Prince. Glasgow, Oxford University Press, 1984.

Morrison, Wayne. Jurisprudence: from the Greeks to post-modernism. London:

Cavendish Publishing Ltd., 2000.

Posner, Richard. Law \& Literature. $3^{\text {rd }}$ Ed. Massachusetts: Harvard University Press, 2009.

Ratnapala, Suri. Jurisprudence. New Delhi: Cambridge University Press, 2011.

Shakespeare and the Law. Eds. Raffield, Paul and Gary, Watt. New Delhi: Mohan Law House, 2011

The Bible. Ed. Harold Bloom. Philadelphia: Chelsea House Publishers, 1987. 